\title{
Adeline Herrou, La Vie entre soi. Les moines taoïstes aujourd'hui en Chine
}

Nanterre, Société d'ethnologie, 2005, 520 p.

\section{David Palmer}

\section{OpenEdition}

\section{Journals}

Édition électronique

URL : http://journals.openedition.org/chinaperspectives/580

DOI : $10.4000 /$ chinaperspectives.580

ISSN : 1996-4617

\section{Éditeur}

Centre d'étude français sur la Chine contemporaine

Édition imprimée

Date de publication : 1 février 2006

ISSN : 2070-3449

\section{Référence électronique}

David Palmer, «Adeline Herrou, La Vie entre soi. Les moines taoïstes aujourd'hui en Chine », China

Perspectives [En ligne], 63 I january - february 2006, mis en ligne le 20 décembre 2006, consulté le 24 septembre 2020. URL : http://journals.openedition.org/chinaperspectives/580 ; DOI : https://doi.org/ 10.4000/chinaperspectives.580

Ce document a été généré automatiquement le 24 septembre 2020

(c) All rights reserved 


\section{Adeline Herrou, La Vie entre soi. Les moines taoistes aujourd'hui en Chine}

Nanterre, Société d'ethnologie, 2005, 520 p.

David Palmer

\section{NOTE DE L'ÉDITEUR}

Translated from the French original by Philip Liddell and David Palmer

1 La Vie entre soi ("Life Amongst Oneselves") is an anthropological study of the dominant institution of contemporary Chinese Taoism, the Quanzhen order, which is distinguished by its monastic organisation. The study is based on extensive field research focused on a temple in southern Shaanxi. It offers a general depiction of life in a Taoist monastery, describing the initiation process by which the monks leave normal life and enter the religious order; and it identifies the unique characteristic of this parallel world : its break with the kin-based organisation of lay society, associated with an alternative set of pseudo-kinship relationships designed to transcend sexual differences.

2 The first part of the book presents the ethnographic backdrop of the study. Its four chapters describe the religious buildings of the Wengong Temple, the monastic community, the lay believers who attend the temple, and the deities worshipped there. Wengong Temple stands in the old quarter of the city of Hanzhong, in the south of Shaanxi province, in a valley of the river Han not far from Sichuan province. The temple itself, three courtyards huddled together, is unremarkable. It is far from rivalling the more famous of the great monasteries or those of sacred mountains such as Qingchengshan, Huashan or Wudangshan. According to legend, the temple is associated with Zhang Lu's first community of Heavenly Masters. Zhang Lu founded an independent principality in this region towards the end of the second century, but the building is first mentioned as a temple to the god of the soil in local monographs of the Qing Dynasty. Not until the start of the twentieth century did it become a Taoist 
monastery dedicated to the Wengong cult; and it attained its greatest prosperity before the Second World War. The temple was confiscated at the end of the 1950s, but the monks gradually repossessed it during the 1980s ; since then, they have carried out a ceaseless programme of structural improvements, so that the building today is larger than it ever was in the past.

3 Adeline Herrou compares the various oral and written versions of the temple's history and explains how, in practical terms, the temple's reputation was built up around this sacred place. She goes on to describe the community of Taoist monks who live there, based on such views of them as the visitor is allowed. First she depicts the monks' clothing, their ritual costumes, their hair (worn in buns on top of their heads) and their headgear, explaining the symbolic meanings. Next, she discusses the enigmatic image of the monks, speaking in their own private jargon and carrying themselves with unvarying reserve. Then she explains how the monks conceive their own identity, comparing it with that of other groups both within and without the monastic community : as Quanzhen monks in relation to the non-monastic Heavenly Masters, as descendants of the Longmen lineage in relation to other Quanzhen lineages, and as members of a network of temples in southern Shaanxi. They are also persons "who have left their families" (chujia), a status they share with their Buddhist counterparts. Herrou then sets out the genealogy of the teaching tradition of most of the monks in the temple, contrasting the Wengong temple as a "hereditary temple" (zisun miao) passing on its practices from master to disciple, with the great "ecumenical monasteries" (conglin miao).

4 Lastly, Herrou explains the distinctions made by monks between those "from here" and those "from elsewhere", and between those who were monks before the Cultural Revolution and those who have recently entered the order. This chapter offers interesting data on how the Hanzhong monks see themselves in relation to other Taoists. It suffers, however, from a weakness to be found in several of the book's later chapters : the reported speech of the author's informants is mixed up with summaries drawn from sinological literature on the subject, with no clear distinction between the two. For example, in the section on relations between the Hanzhong monks and the Heavenly Masters, the writer asserts that the Hanzhong monks "maintain an ambiguous relationship" with the Heavenly Masters (p. 111), that they "speak quite often" about them, but that they are "little known" because they are "rare in the region" (p. 115). The reader is curious to know why they speak so much about these masters whom they have never met. And what do they say about them ? But instead of supplying this ethnographic data, the writer gives a very brief historical outline of the Heavenly Masters tradition, of the foundation of the Quanzhen order, and of the relations between the two based on the sinological literature. But what is really happening in the field ? If they have very few direct contacts with those secular Taoists, why are the monks fascinated by them ? It seems to me, judging from my own limited experience, that they represent, for the Quanzhen monks, the image of the nonmonastic Other : Taoist priests who live freely in society, with their families, and earn their living by conducting ritual services. The Zhengyi priests who are seen to incarnate the Heavenly Masters, are the group in contradistinction to which the celibate and "transcendental" identity of the monastic community is defined; in addition, they present the fascinating possibility of being Taoist without breaking one's links with sexual, family and economic life. 
Chapter Three is devoted to the lay people who frequent the temple. The writer divides them into two categories: there are the "simple pilgrims" (xinshi) who attend the temple from time to time to pray to the deities and who do not necessarily have any particular link with the Wengong temple or with Taoism; and there are the "lay believers" (jushi) who have very close links with the monks, forming a real community which takes part in daily tasks and in the management of the temple, and who consider themselves as Taoists. Next, the writer turns to the role of the state in the administration of the temples, showing how the hierarchical system of official Taoist associations at the national, provincial, municipal and local levels is complemented by the traditional networks of affiliation and by the movements of the monks among the temples.

6 The fourth chapter presents the history and the present-day development of the cults of the temple's deities. The writer recounts the story of the main deity, Wengong, who was originally the mandarin $\mathrm{Han} \mathrm{Yu}$ (768-824), famous for his diatribe against Buddhism, which ended in his being exiled to southern China. Herrou has the commendable intention of comparing various sources on the deification process and on how legends have been created around this figure; but the result is a mixture of data from the Hanzhong monks, Chinese historians, sinologists, and French missionaries, with the sometimes unfounded speculations of the author herself-for example, the idea that Wengong governs the "Heavenly Gate" (the mouth) in Interior Alchemy (p. 220). This otherwise most interesting section on how this improbable deity evolved, would have been more successful had the writer made clearer distinctions between various sources, and compared what really concerns us here: the local stories about the deity as recounted by the Hanzhong monks, the lay believers, and the city inhabitants-these three groups having perhaps different stories to tell-with the official reputation of Han Yu as built up by Chinese historians. The section ends with an examination of the ongoing changes in the hierarchical positioning of the temple's other deities in relation to each other, and with an analysis of the role of the cults of particular deities in the network of temples.

Having devoted half the book to this ethnographic picture of the Wengong temple-its site, its officiants, its pilgrims and its deities-the writer examines, in the second and third parts, the community of Taoist monks, taking as her point of departure the anthropological theory of kinship to explain what it means to be a monk. She looks first at the reasons that have prompted the monks and nuns to "leave their families" (chujia) and enter monasteries, then, in reference to kinship theory, she compares the institution of chujia to that of marriage : like the marriage of a young woman, chujia implies leaving one's own original line of descent to join a new one (in this case, the pseudo-kinship structure that governs relations between Quanzhen monks). But unlike what happens in marriage, there is no exchange or alliance. The monks cut all links with their families without any new ties being formed between the original families and the monastic communities. Next the writer looks at cases in which monks have broken the celibacy rule : some have gone back to live with their former wives without breaking with the monastic order; others have had sexual relationships outside the monastery. Examining the severity of sanctions imposed on monks who have broken the celibacy rule, she observes that breaches of the rule outside the precincts of the monastery are tolerated, but that living as a couple, or with one's own children, inside the monastery is punished by ostracism or expulsion : "Above all, it is family life within 
the precincts of the monastery that is proscribed and, most particularly, the conjugal or filial relationships that monks have renounced on first taking holy orders. And this change of life is, in the end, the one irreplaceable condition of monastic life" (p. 291).

Chapter Six describes the initiatory process whereby the candidate prepares himself (or herself) for admission to the monastic community. Over a period of about three years they will have the status of "Tao-child" (tongdao) : they must find themselves a master, live in the monastery and adapt to monastic life. There is no formal apprenticeship : the novice must serve their master in all aspects of daily life. Herrou goes on to list the rules governing that existence, again citing various examples from the sinological literature and the "observances of Taoist life" prescribed by the Taoist Association of China, but gives few details on how the precepts are applied in the Wengong temple. After that, we learn of the ritual investiture at which novices acquire monastic status and are given the Taoist headgear and habits; and we look at the procedure for assigning to the monks their Taoist names, giving them their formal places in the educational genealogy and defining their relationships with the other monks. Lastly the writer describes the forms of communication and apprenticeship, both traditional (non-discursive, through imitation and questioning) and modern, through the Taoist Academy in Beijing The latter, from the perspective of the Wengong temple, is considered as an elite school, extremely difficult to gain admission to, primarily on recommendation from provincial Taoist associations.

In Chapter Seven, the author describes the monks' religious and spiritual activities, beginning with those designed to serve others: calculating auspicious dates at the request of the faithful, holding temple fairs, subsidiary rites, and occasional rituals. She goes on to outline how the monks work towards spiritual self-improvement : the quest for immortality, asceticism and interior alchemy.

The following chapter deals with the role of wandering in the life of monks : becoming a monk means cutting oneself off from the land of one's birth and spending one's existence alternating between long stays in a single monastery and periods spent wandering across China's network of temples and holy places. Herrou describes how custom governs these travels and how wandering monks are received in the monasteries ; she lists the factors influencing the monks' choice of itinerary, including the notion of "predestined affinity" (yuanfen); she gives details about the networks of connections, and the different kinds of journey undertaken : wanderings to the sacred mountains, which are simultaneously inner journeys ; initiatory travels in the steps of the great Masters, and ad hoc trips for celebrations and meetings. Here again, Herrou combines data drawn from the sinological literature with comments from the monks of Hanzhong, and again without making much distinction between the discourse on asceticism and its practice. But, bearing in mind that ascetic practices are individual and carried on in secret, in the monks' invisible intimacy, it is almost impossible for the ethnologist to observe what is, at least in principle, supposed to be the Quanzhen monks' fundamental activity.

11 In its third part, the book re-examines the monastic community in light of anthropological kinship theory. Becoming a monk means "leaving the family" (chujia), and at the same time joining a new family: the organisation of relations between monks is modelled on the family, with the monks even borrowing kinship terms in referring to each other and in identifying relationships between generations and religious traditions. So the monks form a pseudo-kin group. This type of organisation 
partly solves the problem created by having no descendents to hold a cult for them, which condemns them to death without progeny, the worst fate in Chinese culture. It is the pseudo-kin group of the monks who carry out specific rites to accompany the dead soul to his new celestial home. One further aspect is significant. Although monasteries admit both monks and nuns and there is no strict division in gender roles, the kinship terms used are exclusively masculine and patrilineal : a female fellow-disciple initiated earlier than another would be, for example, called her "elder brother" (shixiong), no regard being paid to biological age The pseudo-family group expunges all differences between the sexes. Herrou links this practice with the ban on sexual relations between members of the monastic community: since the monks and nuns are members of the same pseudo-kin group and, furthermore, since they all use kinship terms of the same sex (male), any sexual relations between them would amount, in the logic of kinship, to a form of incest. The writer also reports the explanation offered by the monks themselves: their aspiration to a state of pure Yang. At the same time, the monks cultivate the Yin principle, to the extent of adopting female behaviour such as squatting in order to urinate. To summarise, the monks, who internalise their sexuality by interior alchemy, are sometimes Yang and sometimes Yin in their quest to sublimate their differences and to unite in oneness.

Pointing out the extent to which the monastic community is modelled on kinship structures, the writer wonders whether anthropological categories of the family might be extended more generally to religious groupings that form pseudo-kinship organisations. In the case of the Taoists, she suggests that one should consider the transmission of texts and sacred records as the element of filiation substituted for consanguinity.

La Vie entre soi is a rich source of information on the life of monks. The monastic community of the Quanzhen order lends itself ideally to a classical anthropological approach : it is a real "tribe" with its own place, members, rituals, culture and internal organisation; although it exists within society, it clearly and consciously holds itself distinct from it. The thorough analysis of the "kinship" model of monastic organisation, with the help of anthropological theory, is particularly revealing and a significant innovation in the study of Chinese monasticism. 